\title{
Podrijetlo i kultura moliških Hrvata u kontinuitetu kršćanske tradicije
}

\author{
Marta Račić*
}

\begin{abstract}
Sažetak
Moliški Hrvati na jugu Italije prisutni su više od pet stoljeća. Prošli su dug povijesni put od potpune anonimnosti i izoliranosti do otkrivanja u površnom i pogrešnom imenu Slavi, kojim su ih kroz povijest nazivali Talijani. Upravo zbog toga, mnogi putopisci i znanstvenici s početka 20. stoljeća pogrešno su ih definirali kao Bugare, Srbe ili Crnogorce. Sredinom 20. stoljeća vraćeni su nazivom tamo kamo po svojem podrijetlu i pripadaju, da su Hrvati, katolici, iseljeni uslijed ekspanzije Turaka u 15. i 16. stoljeću iz podbiokovlja i makarskoga primorja između rijeka Cetine i Neretve. Do danas su sačuvali svoj govor, štokavsku ikavicu s elementima čakavštine.

Cilj je ovoga rada predstaviti jezik $i$ kulturu moliškohrvatske zajednice u kontinuitetu kršćanske tradicije koju oni žive kroz svoje vjerske običaje. Kršćanska tradicija dio je njihove vjerničke svijesti i bitno je utjecala na oblikovanje kulture po kojoj su i danas prepoznatljivi u lokalnom, ali i širem europskom okruženju.
\end{abstract}

Ključne riječi: moliški Hrvati; identitet; vjerski običaji; tradicijska kultura; Slavi

\section{Uvod}

Moliški Hrvati žive danas na području talijanske pokrajine Molise u selima Kruč (tal. Acquaviva Collecroce), Filič ${ }^{1}$ (tal. San Felice del Molise), Mundimitar (tal. Montemitro) i Tavela (tal. Tavenna). ${ }^{2}$ Pokrajina Molise nalazi se u južnom

* Dr. sc. Marta Račić, Vanjska suradnica Fakulteta hrvatskih studija Sveučilišta u Zagrebu, Adresa: Borongajska cesta 83d, 10000 Zagreb, Hrvatska. ORCID iD: https://orcid.org/0000-00026253-1654. E-adresa: martaracic60@gmail.com

1 Za selo San Felice del Molise hrvatsko je ime Filič. U literaturi se susreće i ime Stifilić, što moliški Hrvati smatraju pogrešnim, jer im je Stifilić ime svetca zaštitnika.

2 Naselje Tavela tek je od 2017. dobilo status povijesne jezične manjine. Pravni status odobrilo je Pokrajinsko vijeće (Il Consiglio Provinciale di Campobasso) na zahtjev Općinskoga vijeća (Il Consiglio comunale), a potom je prema Zakonu o zaštiti povijesnih i jezičnih manjina (Zakon 482/99) općina Tavela uvrštena u područje na kojem se hrvatski jezik štiti kao priznati jezik povijesne jezične manjine moliških Hrvata. Demografski podatci o broju Hrvata u Taveli nisu poznati, a kod stanovnika ne postoji kontinuitet u življenju hrvatskoga jezičnoga i kulturnoga identiteta 
dijelu Italije između većih pokrajina Abruzzo i Apulija (tal. Puglia), s glavnim gradom Campobasso. Jednim svojim dijelom pokrajina Molise se spušta prema Jadranskom moru, na kojem su smještena dva veća grada, Termoli i Vasto, prema kojima danas gravitiraju i stanovnici hrvatskih naselja i kamo odlaze svakodnevno na posao i u školu.

Koliko je moliškohrvatska zajednica malobrojna najbolje govore podatci o broju stanovnika u ta četiri naselja. Kruč danas broji 625 stanovnika, Filič 603 stanovnika, Mundimitar 336 stanovnika, a Tavela njih 673 (Geo Demo, Demografia in cifre, Istat). Broj je stanovnika od kraja Drugoga svjetskoga rata u stalnom opadanju, jer mladi odlaze na školovanje ili traže poslove, a ostaje uglavnom starije stanovništvo. Danas su moliški Hrvati i dalje iseljenici i imaju svoju dijasporu po svim kontinentima, a mladi se školuju u mnogim gradovima Italije, gdje često ostaju živjeti. Ono što je za moliškohrvatsku zajednicu kroz povijest bilo bitno njihova je usmjerenost na prenošenje i čuvanje jezika i običaja. Uz to, vjera i pripadnost Katoličkoj crkvi nikada nisu bile upitne. Živjeli su svoju duhovnost kroz vjerske običaje, stopljeni kroz tu dimenziju s talijanskim stanovništvom. Možda je upravo ta činjenica dolaska u područje jake rimokatoličke vjere, koja ih nije razlikovala od domicilnoga stanovništva, olakšala i bila uzrokom lakšega procesa asimilacije tako velikoga broja doseljenika.

Talijanski jug još je od vremena antike, a kasnije i kroz srednji vijek, uvijek bio zanimljivo imigracijsko područje. Različite doseljeničke skupine, zbog teritorijalne izoliranosti i okruženosti morem, postupno bi se stopile s okolnim stanovništvom, ali je cijelo područje bilo i ostalo etnički raznoliko (Heršak, 1987). Među skupinama aloglota koje su se do danas održale na talijanskom jugu u neposrenoj blizini moliških Hrvata, pa su nam stoga i zanimljive, još su Grci i Albanci. Obje etničke zajednice uspjele su očuvati svoj identitet, između ostaloga i zato što su se vjerski razlikovale od Talijana (Heršak, 1982, 19). Međutim, kod moliških je Hrvata jezik, koji sami nazivaju govor na-našo ili na-našu, ${ }^{3}$ bio glavni označitelj njihova identiteta, i zbog njega su se do danas održali kao prepoznatljiva manjinska zajednica. U kontekstu identiteta jezik ima komunikacijsku i manifestativnu službu, jer se njime služe pojedinci kao članovi društva koji definiraju, izražavaju i prenose određenu kulturu (Grbić, 1998). Moliški su Hrvati upravo na jeziku razvili brojne aktivnosti, od kojih treba istaknuti najrecentnije kao dokaz trajanja u vremenu, a to su izdavačka djelatnost u okviru Zaklade Agostina Piccoli i literarni natječaj Fondazione Piccoli. Od 2002. godine taj natječaj u pisanju poezije na jeziku moliških Hrvata završava književnom večeri i dodjelom nagrada pod

koji je moguće pratiti u ostala tri naselja, stoga se kao primjeri spominju samo Kruč, Filič i Mundimitar. U Taveli, koja za sada ima samo pravni status povijesne jezične manjine, postoje inicijative za projekte oživljavanja jezičnoga i kulturnoga identiteta, ali ovisi o samim stanovnicima koliko će se takvih programa i realizirati. Podatci o naselju Tavela i njegovu političkom statusu dobiveni su s terena od gospodina Pasqualina Sabelle. Više o statusu moliških Hrvata u Italiji usp. Muljačić, 2007, 26-47.

3 U tri hrvatska naselja postoje određene jezične razlike, pa u Kruču govore na-našu, a u Mundimitru govore na-našo. 
naslovom Večera na-našo, što je postalo istaknutim kulturnim događajem i za Talijane koji žive u okolici (Račić, 2017, 79).

U ovom radu predstavljen je onaj dio povijesti, života i običaja moliških Hrvata koji ukazuje na konstantu njihova kršćanskoga bića, koje je ostavljalo traga u svim područjima života. Negdje je taj trag najvidljiviji kroz jednostavno održavanje vjerskih i narodnih običaja, a najvažniji je u dosljednom življenju istine o podrijetlu, koju su moliški Hrvati prenosili s koljena na koljeno. Najvažnija istina bila je da su njihovi stari došli z'one bane mora jednoga petka u mjesecu svibnju i da je za cijelu zajednicu, a posebice za mlade naraštaje, najvažnije bilo sačuvati naš lipi jezik kao razlikovno obilježje i bogatstvo.

U prvom od pet poglavlja predstavljeni su putopisci, književnici i svećenici, kako s talijanske, tako i s hrvatske obale, koji su od 17. stoljeća bilježili susrete i podatke o Hrvatima na talijanskom jugu. Tragom tih napisa može se pratiti kontinuirano zanimanje za doseljenike koje su nazivali Slavima, a koje se tek početkom 20. stoljeća počinje sustavno istraživati, najviše njihov jezik i običaje, koje su u izoliranim brdima talijanskoga juga uspjeli sačuvati. Tim doseljenicima iz Dalmacije po svojem podrijetlu pripada isusovac i jezikoslovac Jakov Mikalja, stoga je i bilješka o njemu uvrštena u ovo poglavlje.

Nadalje su u ovom radu predstavljena glavna istraživanja o podrijetlu moliških Hrvata, a potom i promicatelji njihova identiteta, čija je uloga bila presudna za pokretanje revitalizacijskih procesa unutar zajednice, ali i za njihov kontinuitet. Proces revitalizacije započinje zanimanjem za vlastiti identitet, koji je u zajednici očuvan najviše zahvaljujući jeziku kao osnovnom razlikovnom obilježju u odnosu na susjedne talijanske i imigrantske zajednice juga Italije (Perinić, 2006). Važan su dio tradicijske kulture moliških Hrvata običaji vezani uz kolektivno sjećanje na dolazak u novu domovinu, kao što je Fešta do Maja u Kruču ili Fešta do kapele u Mundimitru. U istom poglavlju predstavljeni su vjerski običaji vezani uz blagdan Božića, koji su ponovno oživljeni u tri moliškohrvatska naselja. To su paljenje ognja na Badnju večer u Kruču i Mundimitru i žive jaslice po ulicam i trgovima povijesne jezgre u Filiču.

Zadnje je poglavlje posvećeno kardinalu Franji Šeperu (1905.-1981.), koji je od 1968. do 1981. godine za vrijeme boravka u Rimu posjetio moliške Hrvate u više navrata. Iz tih susreta pokrenut je pastoralni rad, jer su u Molise bile upućene dvije časne sestre iz Rima, a kasnije i franjevac Petar Milanović iz Splita. On je u svojstvu kazivača dao bitan doprinos ovoj temi, rasvijetlivši neka pitanja osobnim iskustvima župnika koji je u Kruču i Mundimitru, s kraćim prekidom, proveo punih sedamnaest godina.

\section{Spomeni moliških Hrvata od 17. stoljeća}

Najstariji hrvatski zapis o kolonijama u južnoj Italiji, prema pisanju Jelke Vince Pallua, seže u 17. stoljeće, a ostavio ga je isusovac Bartol Kašić još 1613. godine u svojoj Autobiografiji, u opisu misionarskoga putovanja kroz Italiju. S toga je putovanja opis susreta s Hrvatima, koji se je dogodio kod mjesta Bovino u 
Irpiniji, točnije na pola puta između Napulja i Foggie. Susret se odigrao u jednoj seljačkoj kući, gdje je domaćica putopiscu i njegovoj dubrovačkoj pratnji naznačila da je prisutna osoba koja može razumjeti njihov govor, stoga da budu oprezni kada govore o državnim stvarima. U kasnijem razgovoru s jednim od stanovnika Bartol Kašić bilježi da postoje doseljenici iz Dalmacije te da su njihovi pređi doselili i sklonili se bježeći pred Turcima, izgradili kuće, a između sebe uvijek se služe dalmatinskim govorom. Također je saznao i podatak da imaju katoličke svećenike rimskoga obreda koji im dijele sakramente, da su mnogi već naučili talijanski jezik i mogu obavljati poslove s Talijanima i razgovarati s gospodarima. Navedeno je da obrađuju polja, uzgajaju stoku, stada volova, goveda i konja po brdima i poljima te rade kao pastiri prema drevnom običaju svojih pređa (Vince Pallua, 1996, 20-23). Iz toga teksta Bartola Kašića saznaju se izuzetno vrijedni podatci o Hrvatima u tom dijelu Italije, koji su sljedeći: riječ je o doseljenicima iz Dalmacije, jer se služe dalmatinskim govorom i katoličke su vjere rimskoga obreda. ${ }^{4}$ Iako se u putopisu Bartola Kašića ne govori izrijekom o Hrvatima iz pokrajine Molise, jasno je da se to odnosi na šire područje talijanskoga juga, koje je u to vrijeme bilo nastanjeno prekojadranskim kolonistima.

Talijanska strana također je pokazivala zanimanje za hrvatske doseljenike, njihove običaje, pjesme i nepoznati jezik, pa u to vrijeme nastaju prvi opisi Hrvata iseljenih u Italiju. Najraniji zapis o običajima hrvatskih doseljenika ili Šklavuna kod talijanskih zapisivača potječe iz 1497. godine, a zabilježio ga je talijanski književnik Ruggero de Pazienza. On je zapisao pjesmu o vojvodi Janku, koju su tada u južnotalijanskom gradiću Gioia del Colle izvodili Šklavuni onako kako ju je čuo, iako nije razumio ni riječi (Belaj, 1998, 340). ${ }^{5}$

Drugi Talijan koji je u 16. stoljeću pisao o hrvatskim doseljenicima bio je prior dominikanskoga samostana u Vastu Serafino Razzi, koji ih je 1577. godine u svojim putopisima Viaggi in Abruzzo opisao kao snažne, vrijedne i mudre gospodare svoje zemlje, koji upravljaju svojim imanjima, uzgajaju stoku, grade kuće i ostale radionice, a među sobom su zadržali svoj jezik (Šimunović, 1984, 55). Serafino Razzi također je pisao u Cronica Vastese (1576.-1577.) kako su Slaveni, došavši preko mora, osnovali u Molizama naselja San Felice, Montemitro, Collecroce, Patticata, Palata, Tavenna, Ripalta, S. Giacomo degli Schiavoni. U Rimu je za hrvatsku (ilirsku) pastvu osnovana Ilirska bratovština sv. Jerolima, koju je potvrdio papa Nikola IV. (1452.), o čemu je Serafino Razzi također pisao u spomenutoj Cronaca Vastese (Šimunović, 2011, 191).

U 17. stoljeću u Italiji je živio, a tu je i rođen Jakob Mikalja, talijanski leksikograf hrvatskoga podrijetla, izravni potomak doseljenika iz Dalmacije. Njegova je obitelj bježeći pred Turcima u 16. stoljeću stigla u južnotalijansku pokrajinu Apuliju, gdje je tada osnovano nekoliko kolonija slavenskih izbjeglica. Jakob Mi-

4 Jelka Vince Pallua podatke o dalmatinskom govoru, Dalmaciji i pripadnosti katoličkoj vjeri navodi prema autorima: Vanino, 1940; Vitale, 1794.

5 Tekst te pjesme predstavlja našu prvu zapisanu bugaršćicu. O okolnostima u kojima je ona zapisana, prenijeta, ali i otkrivena usp. Šimunović, 1984. 
kalja bio je isusovac, rođen 1601. godine u mjestu Peschici na poluotoku Garganu u pokrajini Apuliji. Njegov je veliki doprinos talijanskoj i hrvatskoj leksikografiji u izradi hrvatsko-talijansko-latinskoga rječnika čiji hrvatski naziv glasi Blago jezika slovinskoga ili slovnik u kom izgovaraju se rieči starinske latinski i diački. Vezu s domovinom predaka kontinuirano je održavao kroz svoju djelatnost, a to je bio znanstveni rad (Jernej, 1951).

Dva stoljeća kasnije, 1856. godine hrvatski je putopisac Ivan Kukuljević Sakcinski putujući po Italiji od Foggie do Napulja pronašao podatke o naseljima u kojima se od 15. do 17. stoljeća govorilo hrvatskim jezikom (la lingua schiavona), ali i mjesta s još uvijek živim hrvatskim govorom. U njegovu tekstu Putne uspomene iz Hrvatske, Dalmacije, Albanije, Krfa i Italije nalazimo podatke o selu Villanova kod Ariana, u kojem su stanovnici još 1584. odbili svećenika Talijana, kojega su im nametali, i tražili »popa Dalmatina ili Hrvata, kao što su imali g. 1549. njekoga fra. Marka Dragonića, a g. 1596. nadpopa Ivana Bigota Dalmatinca iz Ginestre«. Mnoga sela koja su utemeljili Hrvati imala su pridjev degli Schiavoni, pa tako Ginestra degli Schiavoni, Polcarino di Schiavoni, a navodeći šira područja u kojima »još i danas jezikom svojim govore, dok su se u ostalih mjestih većom stranom potalijančili, Kukuljević Sakcinski spominje okolicu Ariana, Abruzzo, Otranto, Contado di Molise« (Kukuljević Sakcinski, 1873, 113).

Niz je talijanskih etnologa istraživača koji su se u drugoj polovici 19. stoljeća bavili pitanjima slavenskih kolonija u južnoj Italiji. Moliški Hrvati kroz povijest učestalo su bili predmetom istraživanja, ali nikada ih se nije precizno definiralo s obzirom na podrijetlo, jezik i kulturu. ${ }^{6}$ Prvi je to učinio Milan Rešetar, a nakon njega sve do sredine 20. stoljeća pisali su najčešće o njihovu jeziku hrvatski dijalektolozi, da bi ih se konačno zasluženo smjestilo u povijesne i zemljopisne okvire pradomovine iz koje su krenuli preko mora.

\section{Podrijetlo moliških Hrvata}

U vrijeme velikih seoba koje su se zbog turske ekspanzije odvijale tijekom 15. i 16. stoljeća iz Dalmacije prema zapadnoj obali Jadrana, iselilo je mnogobrojno stanovništvo. Tada je područje koje su doseljenici nastanili pokrivalo znatno šire krajeve talijanskoga juga, ali ono što je u povijesnim zapisima zabilježeno je da se radi o doseljenicima upravo iz Dalmacije, prebjezima, da se služe dalmatinskim govorom i da su katoličke vjere rimskoga obreda (Vince-Pallua, 1996, 23).

Sustavna znanstvena istraživanja o Slavima na širem području talijanskoga juga započeo je već spomenuti hrvatski filolog Milan Rešetar, kojega je 1907.

6 Krajem 19. stoljeća javljaju se napisi o doseljenicima na jugu Italije. Ruski povjesničari V. Makušev i S. M. Drinov nazivaju ih bugarskim potomcima. Srpski učitelj iz Boke Risto Kovačić 1885. godine objavio je rad u kojem bez ikakve povijesne ili jezične utemeljenosti navodi: »uzmite kartu Italije, pogledajte $u$ istočnu joj obalu, malko izviše one glavine Gargana što ono gleda u ponosni Dubrovnik miloga nam srpskoga primorja, - naći ćete Molize. Ondje je cvalo devet lijepih srpskih naseobina, od kojih danas ima 16.000 duša « (Kovačić, 1885). Više o različitim teorijama pri utvrđivanju podrijetla slavenskih doseljenika usp. Šimunović, 1984. 
godine na teren uputila Bečka kraljevska akademija. Sam Rešetar navodi da je inicijativa za istraživački rad došla nakon što se dubrovački plemić Medo Pucić 1851. godine vratio iz Napulja, gdje je susreo ljude koji govore na naški. Saznavši da su iz Kruča, stupio je u kontakt s profesorom Giovannijem de Rubertisom te započeo s njime korespondenciju, iz koje je bilo očito da je riječ o sačuvanom arhaičnom govoru te bogatoj kulturi i tradiciji naroda koji je doselio iz Dalmacije, s druge obale Jadrana, a ostale detalje trebalo je tek istražiti (Rešetar, 1907, 1107). Nakon boravka u Kruču, Milan Rešetar objavljuje studiju o jeziku, običajima, nošnji, pjesmama i pričama koje su ti doseljenici donijeli iz svojega kraja. ${ }^{7} \mathrm{Uz}$ detaljne i vjerne zapise s terena i jezičnu analizu govora koja je nakon istraživanja provedena, autor je zaključio da doseljenici, koji govore štokavsku ikavicu s elementima čakavštine, najvjerojatnije potječu iz makarsko-biokovskoga područja između rijeka Cetine i Neretve. Otuda su u nekoliko navrata iseljavali bježeći pred Turcima, krajem 15. i početkom 16. stoljeća (Rešetar, 1911, 51). Tomu u prilog govori i natpis na crkvenim vratima u mjestu Palata, koje su nekoć također nastanjivali Hrvati, a natpis je prije Rešetara, još 1904. godine, zabilježio Josip Smodlaka za svojega posjeta moliškim Hrvatima: »Hoc primum Dalmatiae gentes incoluere castrum ac a fundamentis erexere templum anno 1531. (Dalmatinci prvi naseliše ovaj grad i iz temelja sagradiše crkvu godine 1531.) « (Smodlaka, 1906, 44).

Nakon Rešetara nastavljena su filološka, povijesna i etnografska istraživanja o doseljenju Hrvata na jug Italije, koja su uglavnom potvrđivala njihovo podrijetlo koje je utvrdio Rešetar, no i donosila nove spoznaje o njima (Račić, 2018, 42-44)..$^{8}$

\section{Znameniti promicatelji moliškohrvatskoga identiteta}

Zanimljivo je da u tako maloj zajednici, koja je kroz povijest dugo bila nevidljiva široj javnosti, postoji veliki broj pojedinaca koji su zaslužni za očuvanje i promicanje jezika i kulturnoga nasljeđa. Predani pojedinci pokrenuli su procese revitalizacije još 1967. godine. Imena su to iz sva tri naselja, a među njima je bilo stanovnika najraznovrsnijih struka: učitelji, liječnici, novinari, svećenici, radnici, poljoprivrednici.

Jedan od osnivača Kulturnoga društva Naš jezik, izvan manjinske zajednice, bio je i grkokatolički svećenik Božidar Vidov (1913.-2000.). On je još tijekom studija u Rimu 1950-ih godina upoznao zajednicu moliških Hrvata, otkrio je njihov arhaični jezik i bogato tradicijsko nasljeđe te je ostatak svojega života priku-

7 Studija je 1911. objavljena na njemačkom jeziku pod nazivom Die Serbokroatischen Kolonien Suditaliens, a 1997. godine profesor Walter Breu i Monica Gardenghi sa sveučilišta u Konstanzi uredili su i objavili talijanski prijevod: Le colonie sebocroate nel sud Italia.

8 Dijelovi rada preuzeti su iz disertacije Revitalizacija moliškohrvatskoga identiteta (Račić, 2018). U okviru disertacije obrađeno je poglavlje Dosadašnja istraživanja o moliškim Hrvatima, koje do sad nije objavljeno. 
pljao i objavljivao pjesme moliških Hrvata i promovirao njihovu kulturu. Kako je već krajem 1960-ih godina bio premješten u Kanadu, u Torontu je kroz rad župe sudjelovao u životu hrvatske zajednice. Božidar Vidov je u Torontu 1981. godine objavio prvu zbirku poezije moliških Hrvata pod naslovom Poezije na našu. Za svojega života objavio je jedanaest knjiga i brošura u kojima predstavlja narodne pjesme, gramatiku, dijalektalni rječnik moliških Hrvata, njihov kalendar ili poeziju (Granic, 2009, 268-275).

Od žena bitnih za tu zajednicu bila je Agostina Piccoli (1962.-1998.) iz Mundimitra, koja je ostavila intelektualni i transgeneracijski neizbrisiv trag. Sredinom 80-ih godina 20. stoljeća studirala je u Zagrebu te usavršila znanje jezika, upoznala povijest, kulturu, način života, ali stjekla i brojna prijateljstva u Hrvatskoj. Uspostavila je kontakte s profesorima, kojima je za vrijeme studija bila vrijedan izvor informacija o dijalektu moliških Hrvata, te je otvorila suradnju s pojedincima, ali i institucijama u Hrvatskoj. Na Filozofskom fakultetu Sveučilišta u Zagrebu diplomirala je hrvatski jezik i književnost, a po povratku u rodni Mundimitar pokrenula je nastavu hrvatskoga jezika u sva tri naselja te je započela izradu rječnika Mundimitra. Bila je aktivna u praćenju europskih politika vezano uz manjinske kulture i jezike. Znanje jezika koje je dobila kroz studij bilo je presudno za svijest o vrijednosti manjinske kulture iz koje je potekla, stoga je 90-ih godina bila glavni pokretač svih aktivnosti u zajednici. Nažalost, prometna nesreća i njezina tragična pogibija u svibnju 1998. godine zaustavila je sva događanja i brojne neostvarene planove. Njezin suprug Antonio Sammartino, svjestan vrijednosti koje počivaju u jeziku i kulturi, nakon samo godinu dana pokrenuo je ponovno zajednicu. Nastavio je njezin rad i osnovao Zakladu Agostina Piccoli, kroz koju se i danas ostvaruje bogata izdavačka i kulturna djelatnost (Račić, 2018, 83-86). ${ }^{9}$

\section{Moliški Hrvati i njihovi vjerski i narodni običaji kroz godinu}

Moliški Hrvati slave vjerske blagdane kroz godinu u skladu s kršćanskom tradicijom. To su Uskrs, Božić, Tijelovo, Velika Gospa, kao i sve ostale manje svetkovine. Teško je bez usporednoga istraživanja talijanske tradicije utvrditi koje bi bile sličnosti ili posebnosti u održavanju tih običaja u odnosu na talijansku i hrvatsku tradiciju. Izdvojit ćemo stoga samo običaje koji se vežu izravno uz tradiciju moliških Hrvata.

U sva tri sela ponovno je oživjelo pod različitim nazivima paljenja svetoga ognja na Badnjak. U Kruču se oganj naziva Smerčka, u Mundimitru je to Prlj, a u Filiču Prejo. Kazivači naglašavaju da je to starinski običaj koji je zamro nakon Drugoga svjetskoga rata, a potom je obnovljen 1996. godine u Mundimitru, ali i Filiču i Kruču. Na prostoru ispred crkve u Badnjoj noći zapali se oganj, koji treba održavati, jer se oko njega prije i nakon polnoćke okupljaju mještani u

9 Brojna su imena i drugih zaslužnih promicatelja identiteta moliških Hrvata, a to su najprije svi oni pjesnici koji još od 1967. godine do danas pišu stihove na moliškohrvatskom dijalektu i čuvaju od zaborava sva kolektivna sjećanja koja tu zajednicu i dalje drže na okupu. 
razgovoru i pjesmi te uz nešto vina i kolača slave Kristovo rođenje. U Filiču na Badnjak mještani pripremaju žive jaslice po ulicama i trgovima stare povijesne jezgre, gdje naprave 40 ambijentalnih mjesta sa 180 sudionika u tradicionalnom ruhu s naglaskom na hrvatskoj tradiciji u odijelu, hrani i govoru. ${ }^{10} \mathrm{Za}$ zajednicu moliških Hrvata u Filiču oživljavanje toga običaja važno je radi buđenja interesa mlade generacije za tradiciju, običaje, podrijetlo i jezik, jer se ti elementi koriste kao etnički simboli u prezentiranju jaslica (Anon., 2014).

U sva tri sela čuvaju se običaji koji obilježavaju dolazak Hrvata na prostore današnje Italije. Riječ je o čuvanju uspomene, o kolektivnom sjećanju iz kojega su nestali stvarni događaji i činjenice, ali je kroz stoljeća i generacije tradirao u običaj koji održava zajednicu na okupu. Vjerovanje kaže da su predci moliških Hrvata došli jednoga petka u mjesecu svibnju, a kako se ne zna točno kojega petka, svetkuje se svaki petak u svibnju s jačim naglaskom na prvom i zadnjem. U Mundimitru se slavi prvi petak, ali zadnji je posebno velika svečanost koja započinje svetom misom u 11 sati, zatim procesija prolazi kroz cijelo mjesto s kipom sv. Lucije. Po ulicama su štandovi koji daju atmosferu pravoga proštenja, limena glazba svira, djeca ne idu u školu, a obitelji s djecom šeću selom. U razgovoru s mještanima Mundimitra saznaje se da su prvi i zadnji petak u svibnju i Fešta do kapele za njih i danas najvažnije svetkovine. Ono što ih povezuje lik je sv. Lucije, jer je prema vjerovanju njezin drveni kip narod donio toga svibanjskoga petka iz pradomovine.

Fešta do kapele ili jednostavno Kapela odvija se oko kapele sv. Lucije, u području zvanom Selo, gdje se nalaze i ostatci grobova, pa se pretpostavlja da je na tom mjestu bilo prvotno naselje Mundimitar (Piccoli, 1999, 69-70). Proslava blagdana sv. Lucije ne veže se uz službeni katolički kalendar, tj. 13. prosinca, nego se pod nazivom Fešta do kapele slavi na prvu nedjelju poslije Uskrsa, koja se u talijanskom kalendaru naziva Domenica in albis (Bijela nedjelja). Prema kazivanjima mještana, svečanost počinje u 9 sati ujutro, kad kreće procesija od crkve iz Mundimitra do nekoliko kilometara udaljene kapele na prostoru Selo. U procesiji se moli i pjeva na talijanskom jeziku, a žene nose kip sv. Lucije. Kada se približe kapeli započinje vatromet i zvonjava crkvenih zvona. Po dolasku procesija napravi tri kruga oko kapele u suprotnom smjeru od kazaljke na satu, zatim vjernici ulaze u crkvu i služi se sv. misa, na kojoj se blagoslivlja kruh i dijeli vjernicima. Danas je Fešta do kapele obogaćena i nekim novim elementima, zbog čega se naziva i Sacra dei dolci. Svetkovina i prodaja kolača odvija se poslije sv. mise na prostoru oko crkve, a prikupljeni novac ide za crkvene potrebe i za troškove svetkovine. Na kraju dana kip sv. Lucije nosi se natrag u Mundimitar, gdje po dolasku zvone sva zvona i pozdravljaju sveticu, zaštitnicu mjesta (Račić, 2018, 107-109).

10 U oba primjera, okupljanje u Badnjoj noći oko ognja i žive jaslice u Filiču, simbolično ukazuju na agape, zajedništvo kršćana i braće u gozbi ljubavi. Agape se u navedenim primjerima odvija oko ognja i oko jaslica, jer upravo jaslice donose agape, gozba i zajedništvo se događa oko njih i oko Krista. Na taj način zajednica u ljubavi blaguje i živi agape. 
U selu Filič također postoje svetkovine vezane uz vjerovanje o doseljenju predaka jednoga petka u mjesecu svibnju, ali i Fešta do Kašteja također na nedjelju poslije Uskrsa. Tada vjernici idu na zavjetno hodočašće noseći Gospin kip u crkvu na obližnji Kaštel, što korespondira sa svetkovinom Kapela u Mundimitru (Anon., 2012).

U Kruču je 80-ih godina 20. stoljeća obnovljen običaj Majo ili Fešta do Maja, koji se svake godine održavao na dan 1 . svibnja kao svečanost početka proljeća i obnavljanja prirode. Uz taj običaj vezano je također vjerovanje o dolasku Hrvata u Italiju prvoga petka u mjesecu svibnju. Ophod selom započinjao je prvoga svibnja ujutro, na čelu povorke bio je Majo, tj. snažniji mladić koji je na sebi nosi konstrukciju od granja, trave i cvijeća, njega je slijedila grupa muškaraca prateći ga pjesmom i svirkom. Povorka je nekoć najprije odlazila pred crkvu, gdje bi primili blagoslov svećenika, a potom su prolazili selom želeći obilan urod. Za nagradu su ophodnici dobivali darove u hrani, a s prozora bi žene zalijevale Maju vodom, kao simbol obnavljanja vegetacije i buđenja prirode. Danas je taj običaj prerastao u turističku atrakciju i zabavu, zbog koje na taj dan u Kruč dolaze mnogi iseljeni stanovnici i gosti, a sam ophod je izgubio neke bitne tradicionalne elemente. ${ }^{11}$

\section{Kardinal Franjo Šeper kod moliških Hrvata}

Crkva je kod moliških Hrvata imala višeslojnu ulogu u očuvanju vjerskoga, etničkoga i kulturnoga identiteta, ali ne i jezičnoga. Bogoslužje je nakon ukidanja latinske liturgije uvijek bilo na talijanskom jeziku, a dijalektom se govorilo u obitelji i u svakodnevnom životu. Uloga crkve u toj zajednici kroz povijest bila je bitna u održavanju kršćanske tradicije te običaja vezanih uz crkvene svečanosti koje su zajednicu držale na okupu.

Zanimanje Katoličke crkve u Hrvatskoj za moliške Hrvate veže se uz ime kardinala Franje Šepera i početak njegova boravka u Rimu na čelu Kongregacije za nauk vjere u Vatikanu. Od 1968. do 1981. godine, kada je odstupio s dužnosti i umro, kardinal Šeper četiri je puta posjetio moliške Hrvate. Njegovom zaslugom, ali i nastojanjima mons. Vladimira Stankovića 1981. godine, u Kruč su upućene dvije časne sestre iz Rima. Nakon njih je 1983. godine za župnika u Kruč došao svećenik Petar Milanović, franjevac Franjevačke provincije Presvetoga Otkupitelja iz Splita, koji je među moliškim Hrvatima bio u svojem prvom službovanju do 1996. godine (Grden, 2010). Prema njegovim kazivanjima, u to se je vrijeme razbuktao život u tim župama, uspostavljeni su kontakti s Hrvatskom, ali i s dijasporom moliških Hrvata u Australiji, kamo se je uputila jedna grupa 1994. godine, noseći snimljeni videozapis moliškohrvatskih napjeva. Fra Milanović također naglašava lijepu suradnju s talijanskim biskupima i posebno sa svećenikom Benittom Giorgettom, moliškim Hrvatom iz Termolija koji je svoju biskupiju povezao s crkvom u Hrvatskoj, posebno u vrijeme Domovinskoga rata. Fra Petar 
Milanović vratio se je u Hrvatsku 1996. i tu je ostao sve do 2008. godine, kada ponovno odlazi u Molise, ali tada za župnika Mundimitra. ${ }^{12}$

U rujnu 2008. zagrebački nadbiskup kardinal Josip Bozanić boravio je u Kruču te je predvodio misno slavlje povodom preuzimanja pastoralne brige za tri moliškohrvatske župe, Kruč, Filič i Mundimitar, koje pripadaju biskupiji Termoli-Larino. Tada se među moliške Hrvate vratio fra Petar Milanović i još dvojica svećenika koji su u Kruču, Filiču i Mundimitru ostali do 2012. godine.

Danas u te tri župe nema svećenika iz Hrvatske. Prema kazivanjima fra Petra Milanovića, Kruč trenutačno nema svojega župnika. U crkvu sv. Marije Ester dolazi svećenik iz obližnjega Castelmaura, koji nakon bogoslužja odlazi i zatvara crkvu. U crkvi sv. Lucije u Mundimitru na službi je župnik don Angelo Giorgetta, svećenik iz moliškohrvatske zajednice koji trenutačno vodi pastoral i predano radi na očuvanju i promicanju tradicije i kulture moliškohrvatske zajednice. U Mundimitru je prije tri godine zatvorena i osnovna škola zbog maloga broja učenika.

Vidljivi trag u vjerskom životu zajednice ostavio je kardinal Franjo Šeper, čije ime danas nosi jedna ulica u Kruču te dom za umirovljenike "Hiža za čeljadi stare kard. Franjo Šeper”. Ulicu Franje Šepera i Hrvatsku ulicu otvorio je 1984. godine za svojega posjeta Kruču kardinal Franjo Kuharić.

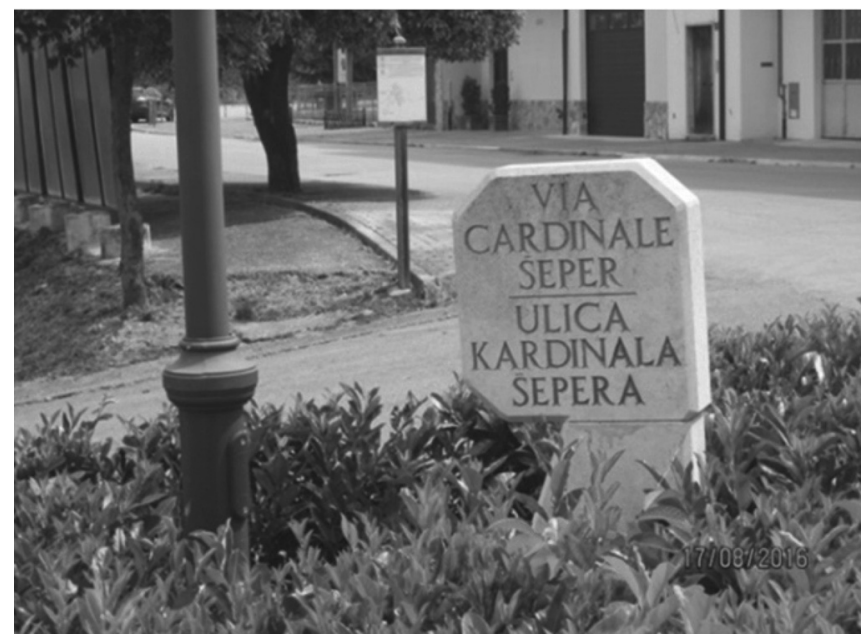

Slika1. Ulica kardinala Šepera u Kruču (Izvor: Marta Račić)

Figure 1. Cardinal Šeper Street in Kruč (Source: Marta Račić)

Ime kardinala Franje Šepera ostalo je zabilježeno u nazivu ulice, jer je on dao povijesni doprinos zajednici moliških Hrvata, a tom gestom oni su pokazali da to znaju cijeniti. Ključna je bila njegova inicijativa, slanje časnih sestara i svećenika, čime je pokazao da shvaća potrebu približavanja te stare hrvatske dijaspo-

12 Podatci o pastoralnom radu fra P. Milanovića dobiveni su usmenom konzultacijom u listopadu 2019. godine. 
re svojim korijenima. Sedamnaestogodišnji pastoralni rad fra Petra Milanovića odvijao se je u vrijeme oživljavanja kulturnoga identiteta te zajednice i procesa njezina etničkoga osvješćivanja. Stoga začuđuje spoznaja da crkva u Kruču danas nema stalnoga svećenika ni Talijana ni Hrvata, a crkva u Mundimitru, mjestu s manjim brojem stanovnika ima svojega župnika. Ta činjenica svakako upućuje na problem raseljavanja i odlijeva mladih ljudi, ali ne samo to. Moguće je da je riječ o nedostatku inicijative od strane vjernika u Kruču, ali svakako je to znak pasivnosti ili neinformiranosti o tom slučaju i Crkve s istočne obale Jadrana ili $z$ one bane mora. Mogli bismo pretpostaviti i da je riječ o tihoj sekularizaciji i/ili ubrzanoj globalizaciji, koja ubire danak i u najskrivenijim predjelima Europe. Ovo je područje koje zasigurno nudi još veliki broj novih istraživačkih tema, primarno terenskih etnoloških istraživanja.

\section{Zaključak}

Moliški Hrvati danas u Italiji dijele sudbinu talijanskoga juga, a to je sudbina izumiranja. Raseljava se stanovništvo izoliranih sela, a kako pokazuju primjeri moliških Hrvata, škola se u jednom selu zatvara (Mundimitar), u drugom selu crkva nema stalnoga svećenika (Kruč), a u svim mjestima ostaje samo starije stanovništvo. U prošlosti je proces industrijalizacije odveo ljude iz njihovih sela u gradove, a danas ih suvremene tehnologije samo virtualno zbližavaju. U tim društvenim i tehnološkim procesima izgubili su se nužno potrebni elementi za prijenos kulturnih vrijednosti unutar zajednice, a to su ljudi različitih generacija i dobi između kojih bi se prenosile vještine, znanja i vrijednosti.

Što se danas događa kod moliških Hrvata? Kod njih postoji svijest o identitetu, o tome da su posebni te da je jezik, kultura i vjera koju su naslijedili kao zajednica kolektivna vrijednost i nit koja ih povezuje. Stoga su i dalje usmjereni na svoje ishodište iz kojega su niknuli, kako bi to oni sami rekli. Vraćaju se više puta u godini na određene dane, najčešće blagdane kao što su Božić, Uskrs ili ljetne svetkovine Velika Gospa i sv. Roko. Međutim, jedna od najvažnijih svetkovina za Mundimitar je Fešta do kapele, na nedjelju poslije Uskrsa, kada se kip zaštitnice Mundimitra sv. Lucije u hodočasničkoj procesiji nosi u kapelu, gdje iznad vrata s unutrašnje strane stoji natpis "Sv. Luce mol za nas". I reći će mnogi hodočasnici da su upravo te riječi i zadnja molitva koju upute izlazeći svake godine iz kapele, nadajući se ponovnomu dolasku po blagoslov sv. Luce.

\section{Literatura}

Anon. (2012). Na Kapel oš na Kašteja: Dvi fešte štorike: Alla Cappella e al Castello due feste storiche. Riča živa: Parola viva: Džurnal do Fondacijune "Agostina Piccoli", 11(1), 1-4.

Anon. (2014). Živi presepj na Filič: Presepe vivente a San Felice. Riča živa: Parola viva: Nuticje web do Kroati iz Moliza, 13(4), 1-4)

Belaj, Vitomir (1998). Povijest etnološke misli u Hrvata. U: Jasna Čapo Žmegač, Aleksandra Muraj, Zorica Vitez, Jadranka Grbić i Vitomir Belaj (ur.), Etnografija: Svagdan $i$ blagdan hrvatskog puka (str. 337-352). Zagreb: Matica hrvatska. 
Cirese, Alberto M. (1955). La "Pagliara" del primo maggio nei paesi Slavo-Molisani. Slovenski etnograf, 8, 207-223.

Cirese, Alberto M. (1995-1996). Milovan Gavazzi e la "pagliara" slavo-molisana. Studia Ethnologica Croatica, 7-8, 47-52.

Geo Demo. Mappe, Popolazione, Stastiche. Demografia in cifre, Istat. URL http://demo. istat.it/pop2019/index.html. (22.10.2019)

Granic, Stan (2009). From the Other Side of the Ocean: Canada's Božidar Vidov and the Molise Croats of Italy. Migracijske i etničke teme, 25(3), 263-287.

Grbić, Jadranka (1998). Jezik i govor kao komponente pripadnosti zajednici (ogled o jeziku i identitetu). U: Ružica Čičak-Chandi i Josip Kumpes (ur.), Etničnost, nacija, identitet: Hrvatska i Europa (str. 181-189). Zagreb: Institut za migracije i narodnosti.

Grden, Darko (2010). Iz života hrvatskih katolika izvan Hrvatske: Moliški Hrvati: U talijanskome moru tri hrvatska otoka. URL: https://www.mundimitar.it/glas_koncila/ glaskoncila_14_02_2010.htm (21.06.2019.)

Heršak, Emil (1982). Hrvati u talijanskoj pokrajini Molise. Teme o iseljeništvu, 11, 6-49.

Heršak, Emil (1987). Sociohistorijski uvod u problematiku etničkih manjina na talijanskom jugu. Migracijske teme, 3(2), 193-220.

Jernej, Josip (1951). Podrijetlo Jakova Mikalje. Zbornik radova Filozofskog fakulteta u Zagrebu, 1, 613-628.

Kovačić, Risto (1885). Srpske naseobine u južnoj Italiji. Beograd: Glasnik srpskog naučnog društva.

Kukuljević Sakcinski, Ivan (1873). Putne uspomene iz Hrvatske, Dalmacije, Albanije, Krfa i Italije. Zagreb: Tiskom dioničke tiskare.

Muljačić, Žarko (2007). Problemi manjinskih jezika u romanskim državama u Europi. Rijeka: Maveda.

Perinić, Ana (2006). Moliški Hrvati: Rekonstrukcija kreiranja i reprezentacije jednog etničkog identiteta. Etnološka tribina, 36(29), 91-106.

Piccoli, Agostina (1999). Otvoreno pismo Hrvatima. U: Antonio Sammartino (ur.), Ali tagliate: Parole di un libro incompiuto: In ricordo di Agostina Piccoli (str. 125). Vasto: Cannarsa Editore.

Račić, Marta (2017). »Večera na-našo« ili kako moliški Hrvati afirmiraju poeziju svoje manjinske zajednice. Pilar, 12(1), 65-82.

Račić, Marta (2018). Revitalizacija moliškohrvatskoga identiteta (Doktorski rad). Filozofski fakultet Sveučilišta u Zagrebu.

Rešetar, Milan (1907). Slavenske kolonije u Italiji. Srd, 6(24), 1105-1127.

Rešetar, Milan (1911). Die Serbokroatischen Kolonien Suditaliens. Wien: Alfred Hölder.

Smodlaka, Josip (1906). Posjet apeninskim Hrvatima: Putne uspomene i bilješke. Kalendar Svačić, 3, 37-58.

Šimunović, Petar (1984). Šklavunske naseobine u južnoj Italiji i naša prva zapisana bugaršćica. Narodna umjetnost, 21, 53-68.

Šimunović, Petar (2011). Moliški Hrvati i njihova imena. Folia onomastica Croatica. 20, 189-205.

Vanino, Miroslav (1940). Autobiografija Bartola Kašića. Zagreb: JAZU.

Vince-Pallua, Jelka (1996). Doprinos utvrđivanja tragova Hrvata u južnoj Italiji. U: Hrvoje Salopek (ur.), Tjedan moliških Hrvata: Settimana dei Croati del Molise (str. 18-26). Zagreb: Hrvatska matica iseljenika.

Vitale, Tommaso (1794). Storia della regia città di Ariano e su diocesi. Bologna: Salomoni. 
The Origin and Culture of the Molise Croats in Regard to the Continuity of Christian Tradition

\author{
Marta Račić*
}

\title{
Summary
}

The Molise Croats have been present in a region of southern Italy for more than five centuries, where they, despite natural assimilation processes, still live their linguistic and cultural identity in three Croatian villages in the Molise region. Since their arrival in Italy, they have undergone a difficult process beginning with complete anonymity and isolation leading up to false and ignorant or malevolent usurpation by travel writers or scientists, who often misinformed others about their identity, while themselves being wrongly informed about the term Slavi, as used by the Italians.

Finally, in the middle of the 20th century, they were recognised for what they are, in fact, according to their origin, namely, Croatian Catholics who fled to Italy from the Ottoman invasions in the 15th and 16th centuries, leaving the area surrounding the Cetina and Neretva Rivers, the Podbiokovlje area and the Makarska Riviera which they inhabited.

During this time-span they have succeeded in preserving their vernacular - the Stokavian-Ikavian dialect with elements of the C̆akavian. This is a well-known fact about the Molise Croats, however, that which has always strongly characterised their community (but has seldom been mentioned) is their Christian tradition which has been an important factor in defining their identity.

Religious traditions and the consistency of the people in living them are the result of their religious awareness which has significantly shaped their culture and which still renders them distinguishable in their local community.

They are recognised as being different and linguistically isolated, but persistent in preserving and passing on true values which have been interwoven into their everyday lives and which have survived through the centuries in their poetry, customs, prayers as well in their weaving tradition, their cuisine and agriculture which together are representative of their rich cultural heritage.

Key words: Molise Croats; identity; religious customs; traditional culture; Slavi

* Marta Račić, Ph.D. External Research Associate at The Research Institute of Croatian Studies in Zagreb, Address: Borongajska cesta 83d, 10000 Zagreb, Croatia.

E-address: martaracic60@gmail.com 